\title{
THE LAW RULING THE MOVEABLES OF AMER- ICANS MARRIED IN FRANCE OR IN BELGIUM WITHOUT ANY SETTLEMENT OR MARRIAGE CONTRACT
}

Which law governs the moveables of an American married in France or in Belgium, ${ }^{1}$ without making a marriage contract or any settlement whatever? The question at issue becomes of great importance, whenever an American lady marries a Frenchman or a Belgian.

I. According to American and English jurisprudence, the law of the domicil of the husband at the time of the marriage (or the intended domicil) determines the mutual rights of husband and wife to each other's moveables, whether possessed at the time of the marriage or acquired afterwards, without reference to the law where the marriage has been celebrated, or to the law of the country where the marriage is celebrated, or where the wife is domiciled before marriage.?

II. By section $\mathrm{I} 400$ of the Code Civil-which is the statute law of Belgium (and was the law of the Rhine provinces in Germany', but no longer since 1900), there begins from the time of the marriage, between husband and wife, married without a marriage contract, a Communio bonorum, ruled by sections I4OI to 1496 inclusive, of the said Code Civil.

By section I4OI, it is expressly stipulated that all moveables, any interest of invested capital, bonds or shares whatever, all rents, income and returns of real estate, even any real estate whatever acquired during coverture by husband or wife, shall fall into the said community of goods (communautê de biens).

By section I42I, the husband is the only manager and owner of such property.

Therefore, he alone has a right to dispose of it at will, and even without the consent of his wife.

By section 1428 , the separate property of the wife is even subject to the power and right of administration of the husband; he

1 The same law, the Code Civil, is the statute law of each country, with some slight amendments.

${ }^{2}$ A. V. Dicey, ct E. Stocquart, Le Statut Personncl Anglais, t. II. p. 200 . 
can sue in her own rights and on her behalf, but he cannot dispose of her real estate without his wife's consent.

III. According to the rules of private international law, as administered by French and Belgian Courts, where there is no marriage contract, or settlement, the mutual rights of Americans (husband and wife) married in France or in Belgium, to each others moveables, whether possessed at the time of the marriage or acquired afterwards, are determined by the law of the husband's actual domicil at the time of the marriage or the intended domicil, usually called matrimonial domicil. This means the husband's domicil is to prevail, when both parties have not the same one.

IV. The place where marriage is celebrated is of no moment in itself, whenever it appears from circumstances, parties intend to establish their home somewhere else. It might, under certain circumstances (whenever there exists some doubt about the actual or intended domicil), be important in order to find out or prove said domicil or intention.

$A$, an American citizen, domiciled in New York, marries in Paris, B, a French woman, domiciled in France, with the intention to go and live in New York. The rights of the parties to moveables are governed by the law of the State of New York.

$A$, an American citizen, domiciled in New York, marries in London, B, a French woman, domiciled in France, with the intention to go and live in New York. The rights of the parties to moveables are governed by the law of the State of New York.

$A$, an American citizen, formerly domiciled in New York, marries in Paris, B, a French woman, with the intention to go and live in London, where they establish their home. The rights of the parties to moveables are governed by the law of England.

$V$. The actual domicil is of great importance, usually it is conclusive proof for the clear intention of both parties regarding the law which should rule their mutual rights to moveables. However, when indisputable facts show a decided intention to make choice of a matrimonial domicil in another country than the husband's actual domicil, such importance ceases to be conclusive and gives way to the intended domicil.

This prevailing view, the doctrine of tacit contract to regulate the rights of husband and wife to their moveables, either possessed at the time of marriage or acquired afterwards, in cases where there is no express contract, is a principle laid down by 
ancient French jurists, namely by Charles Dumoulin. It seemed to be and was held as a well-established principle in French jurisprudence, a principle to last forever.

But, as Emerson writes, there is no outside, no wall, no circumference to us. Every ultimate fact is only the first of a new series (On circles). This applies to legislation and jurisprudence as well as to any other branch of science or part of human activity and labour.

To ascertain parties' intentions, such as they existed in a long past time, proved, in many cases tried by French and Belgian Courts, to be a matter of the highest difficulty.

VI. In 1883 , in the Revue Critique de Législation et de Jurisprudence, Professor Louis Renault began to object strongly to the old doctrine of Dumoulin; he advocated a total change in French jurisprudence: "Je suis disposé à penser qu'il faut rejeter ici l'idée de convention tacite; cette idée est le plus souvent fausse; elle est un non sens dans le cas d'un contrat annulé."

"Voici comment $j$ 'expliquerais les dispositions légales en cette matière: la loi qui organise la famille et régit les rapports personnels de ses membres règle aussi les rapports pécunaires; ce règlement n'est pas impératif, en ce sens que les parties peuvent lui en substituer un autre, mais il s'impose toutes les fois qu'elles n'ont pas exprimé régulièrement une intention contraire. Ma conclusion serait donc que la loi nationale du mari, qui régit les rapports des époux, détermine en même temps le régime sous lequel ils sont mariés, en l'absence de stipulations formelles." 3

According to some lawyers and jurists, the view of tacit contract is not in conformity with facts; few married people ever think of it; according to M. Renault, as quoted hereabove, it is sometimes nonsense.

VII. A clear, definite test, easily applied, might become a sounder criterion of civil rights than pást intention or domicil; they advocated the principle of nationality applicable as a law ruling moveables just as it is governing status and capacity. Now some explanation on the rise and growth of the principle of allegiance or nationality may be of some interest, and this will lead to understand how the new doctrine was at once favored by many jurists and some judges.

VIII. In the majority of European countries, allegiance or

${ }^{3} 32$ (nouvelle série 12) Revue Critique de Législation et de Jurisirudence (1883). p. 730 . 
political nationality is the proper test of civil rights. The Courts of such countries, and notably of France and Belgium, in common with the modern school of writers, of whom Baron von Bar, Pasquale Fiore, Francois Laurent, Louis Renault, André Weiss are the representatives, have adopted the doctrine that a person's civil rights are in the cases to which English and American Courts apply the law of his domicil, to be determined, not by such law, but by the law of the country or State to which he belongs by allegiance or citizenship."

This view has been formally embodied-and for the first time, in the Italian Code of 1865 , which enacts:

Lo stato e la capacità delle persone ed i rapporti di famiglia sono regolati dalla legge della nazione a cui esse appartengono; "the status and the capacity of persons and family relations are regulated by the law of the nation to which they belong." (Art. 6 , Codice Civile.)

The Spanish Code of 1889 has followed Italy: Las leyes relativas a los dercchos y deberes de familia o al estado, condicion y capacidad legal de las personas obligan a los espanoles aunque residan en pais e.ttranjero; "the laws concerning the rights and cluties or the status, condition and legal capacity of persons are binding Spanairds even residing in a foreign country." (Art. 9, Codigo Civil). ${ }^{5}$

The German Code of 1900 has substituted the same principle for the law of domicil:: "Die Geschäftsfäligkeit einer Person wird nach den Gesetzen des Staates beurteilt, dem die Person angehört; "the capacity of a person is determined by the laws of the State to which the person belongs."' (Art. 7, Einfiilirungsegetz zum Bürgerlichen Gesetzbuche.)

IX. The principle of nationality generally applies all over Europe, when the United Kingdom stands alone and keeps to the law of domicil.

Spain and Germany made it a rule governing moveables by default of marriage contract. In France, the Court of Cassation

4 For further details, see 23 American Law Review (1889), 77.5.

${ }^{5}$ For further details, see Manuel Torres Campos, Estudios de Derecho International Prizado, p. 26, Madrid (I891); especially on the laws of marriage, E. Stocquart, Spanish Laws on Marriage and their Extraterritorial Effect, 25 American Law Review, (I89I) 82; Leon Medina e Manuel Maranón, Lejes Civiles de España, p. 2 (9th Ed.).

- See as to the former German view, E. Stocquart, Marriage in Private Interiational Law, 23 Anterican Law Review (1889), 965. 
mentioned it for the first time, on the I8th of May, I886, as a ruling principle, in re J. Gabay v. Vewve Gabay. ${ }^{7}$ Since, several clecisions have declared nationality a definite test for the law ruling moveables between parties married without a marriage contract. The proposed convention of The Hague, 1904, gives up the law of domicil, clearly adopts the principle of nationality:

"Si les époux veulent faire un contrat, la capacité de chacun d'eux à cet égard sera déterminé par sa loi nationale, au moment cle la célébration. C'est la loi nationale qui décide s'ils peuvent, au cours du mariage, soit faire un contrat de mariage, soit modifier leurs conventions matrimoniales, à condition de respecter les droits des tiers."

This is what has been called by French jurists: "Le régime matrimonial incorporé dans le statut personnel."

In Belgium, no Courts have positively adopted the new doctrine and the decisions on the present subject are even scarce, but French Courts have, in several cases, decided in favor of the national law of the husband, unless a contrary intention is clearly shown by indisputable facts. This view is strongly advocated by the learned and well-known professor of the University of Paris, M. André Weiss (Traité théorique et pratique de droit international privé, t. III, p. 554).

It may be the view to be generally taken by the Courts in the next future; it is undoubtedly the direction given by this slow but continuous and decided evolution of doctrine and jurisprudence. Emil Stocquart.

\footnotetext{
`Dalloz Périodique, I887, I, 278.
} 